\title{
Impact of Synthetic Insecticides Against Aphis Gossypii Glover, Bemisia Tabaci (Genn.) and Their Associated Predators on Cotton Plants
}

\author{
Madeha E.H. El-Dewy, Aneesa S. Sadek and El- Sayed A. El-Sarand
}

\begin{abstract}
Pyridinecarboxamide and neonicotinoids insecticides are used in small quantity and economically effective for control sucking pests in cotton fields. Therefore, the current study was conducted to evaluate the efficiency of flonicamid, imidacloprid and dinotefuran and its compared with abamectin, carbosulfan, malathion and cholorpyrifos against cotton aphids, Aphis gossypii Glover and whitefly, Bemisia tabaci (Genn.) and its associated predators, Chrysoperle carnea (larvae and adults) and spiders in cotton fields at Sakha Agricultural Research Station, Kafr El- Sheikh Governorate, Egypt during 2017 and 2018 cotton seasons. Seven insecticides were applied at their field recommended rates. The obtained results proved that imidacloprid, flonicamid and dinotefuran were recorded the highest mean reduction of aphids $(92.95,86.36$ and $76.16 \%)$ at 2017 and $(90.95,82.48$ and $78.44 \%)$ at 2018 season. Carbosulfan and chlorpyrifos caused moderate effective against Aphis gossypii, while the least effective compound was malathion. Concerning the whitefly, imidacloprid, flonicamid and dinotefuran statistically exhibited reduction in populations of adults' stage ranged from 67.54-78.46\% in 2017 and 2018 seasons and 71.04$87.26 \%$ reduction in immature stages in both seasons, while carbosulfan was the least effective compound against Bemisia tabaci (adult and immature stages). It is important to note that flonicamid, imidacloprid and dinotefuran were less harmful effect on populations of tested predators than the tested organophosphates and cabosulfan. Accordingly, flonicamid, imidacloprid and dinotefuran are useful choice for use in IPM programs to control these pests in cotton fields.
\end{abstract}

Keywords: flonicamid, neonicotinoid, sucking pests, associated predators.

\section{INTRODUCTION}

Cotton, Gossypium hirsutum L. is one of the most commercially important fiber crops in the world. Many phytophagous pests are encountered on cotton plants from germination to harvesting. Among of which are aphids cotton, Aphis gossypii Glover and whitefly, Bemisia tabaci (Genn.) causing serious damage to plants. In case of heavy infestation, these pests decreased in fiber quality because of stickiness and development of black sooty mold fungi associated with honeydew dropped on the open bolls (Blackman and Eastop, 1984; Forlow and Henneberry,2001). The mold fungi reduce photosynthesis and lessens the market value of the yields it unmarketable (Berlinger,1986). Furthermore, B. tabaci biotypes can transmit more than 90 types of plant virus (Jorge and Mendoza,1995; Hunter \& Polston, 2001).

In many agricultural systems worldwide, it is well recognized that $A$. gossypii and $B$. tabaci populations are resistant to organophosphates, carbamates and pyrethroids insecticides (Horowitz et al., 1998; Li et al.,2001). Therefore, it is imperative to search out some alternatives of highly toxic insecticides and safe to humans and nontoxic to the natural enemies. In this view, there is a field of utilizing the newer chemistry molecules such as pyridinecarboxamide and neonicotinoid which are required in small quantity and economically effective for control of sucking pests in cotton ecosystem (Gourkhede et al., 2015).

Flonicamid is a novel systemic insecticide that belongs to pyridinecarboxamide group and acts as irreversible inhibitor of aphid feeding (Roditakis et al., 2014). This compound was discovered by Ishihara Sangyo Kaisha, Ltd., Japan and launched in many parts of the world such as USA, Brazil, France and Korea Since 2005 (Morita et al., 2007). Dinotefuran and imidacloprid are belonging to neonicotinoid chemical group and interfere with the nicotinic acetylcholine receptors; therefore, they have specific activity against the insects' nervous system (Maienfisch et al., 2001). Therefore, the present study aimed to detect the efficacy of flonicamid, dinotefuran and imidacloprid against cotton aphids, A. gossypii, whitefly B. tabaci and their associated predators on cotton plants under field conditions.

\section{MATERIALS AND METHODS}

Insecticides:

The commercial formulations of the tested insecticides were used:

\section{*Pyridinecarboxamide}

Flonicamid (Teppeki 50\% WG), $N$-cyanomethyl-4(trifluoromethyl) nicotinamide, obtained from ISK Biosciences Europe N.V, Belgium and rate of 45 $\mathrm{g} / 100 \mathrm{~L}$.

\footnotetext{
${ }^{1}$ Plant Protection Research Institute, Agricultural Research Center, Giza, Egypt

Corresponding author: madehadewy96@gmail.com

Received November 08, 2018, Accepted December 06, 2018
} 


\section{*Neonicotinoids}

Dinotefuran (Oshin 20\% WG), (RS)-1-methyl-2nitro-3-(tetrahydro-3-furylmethyl) guanidine, proved by Mitsui Chemicals Agro., Inc., Japan and rate of $125 \mathrm{~g} / 1001$.

Imidacloprid (Rodex 35\% SC), 1-(6-chloro-3pyridylmethyl)- $N$-nitroimidazolidin-2-ylideneamine, obtained from Jiangsu Yangnong Chemical group Co, Ltd, China and rate of $75 \mathrm{ml} / 100 \mathrm{~L}$.

\section{*Avermectin}

Abamectin (Vertimec $1.8 \%$ EC), 5-Odemethylavermectin $\mathrm{A} 1 \mathrm{a}$ (i) mixture with 5-O-demethyl25-de(1-methylpropyl)-25-(1-methylethyl) avermectin A1a (ii), supplied from Syngenta Agro and rate of 40ml/100L.

\section{*Carbamates}

Carbosulfan (Marshal 20\% EC), 2,3-dihydro-2,2dimethylbenzofuran-7-yl (dibutylaminothio) methylcarbamate, obtained from FMC Corporation USA and rate of $27 \mathrm{ml} / 100 \mathrm{~L}$.

\section{*Organophosphates}

Malathion (Malatox 57\% EC), diethyl (dimethoxythiophosphorylthio) succinate; $S$-1,2bis(ethoxycarbonyl)ethyl $O, \quad O$-dimethyl phosphorodithioate, obtained from Chemenova Denmark Co. and rate of $50 \mathrm{ml} / 100 \mathrm{~L}$.

Chlorpyrifos, Dursban 48\% EC, $O, O$-diethyl $O$ 3,5,6-trichloro-2-pyridyl phosphorothioate, obtained from Dow Agro Sciences and rate of 333.3ml/ 100L.

\section{Field study and sampling:}

The experiment of field was carried out at the farm of Sakha Agricultural Research Station, Kafr El-Sheikh Governorate, Egypt during the cotton growing seasons of 2017 and 2018. An area of $3000 \mathrm{~m}^{2}$ and was divided into plot ( $84 \mathrm{~m}^{2}$ each) and sown with cotton seeds ( Gossypium barbadens Var, Giza 94). All recommended agricultural practices were followed throughout the season without any insecticidal treatments. Eight treatments including control were arranged in this area under a randomized complete block design with four replicates (plots). The insecticides were sprayed once on August 10, 2017 and August 13, 2018 by a knapsack sprayer (CP3), the final volume of spray solution demonstrated $300 \mathrm{~L} /$ feddan. Samples of 25 cotton leaves were selected randomly in the early morning from each replicate to count the number of cotton aphid (nymphs and adults) and whitefly (adults) in the field using lens (8x) immediately before the spray and 2, 5, 8, 11 and 14 days' post spray. The chosen leaves were picked up and taken to the laboratory to count immature stages of $B$. tabaci using binocular microscope. At the same time the common associated predators, Chrysoperle carnea (larvae and adults) and spiders were counted on 5 cotton plants from each replicate and examined carefully on whole plant. The reduction percentages of each insect and predator were estimated using the equation of Henderson and Tilton (1955).

\section{Statistical analysis}

The mean numbers of each insect per cotton leaf for all treatments were calculated and subjected to one-way analysis of variance (ANOVA) and compared for significantly by Duncan's multiple range test (Duncan, 1955 ) at 0.05 probability level between treatments using CoStat system for Windows, Version 6.311, (2005).

\section{RESULTS AND DISCUSSION}

Field efficacy of flonicamid, dinotefuran, imidacloprid, abamectin, carbosulfan, malathion and chlorpyrifos against cotton aphids, Aphis gossypii Glover and whitefly, Bemisia tabaci (Genn.) as well as their associated predators were evaluated during 2017 and 2018 cotton seasons. The data were registered in Table (1-6) and Figure (1).

\section{Efficacy of tested insecticides against Aphis gossypii Glover:}

The present investigation in Table $(1 \& 2)$ revealed that the pre-treatment populations of aphids per cotton leaf was in the range of 9.16-16.08 insects in 2017 season, while it ranged from 15.48 to 33.28 insects in 2018.Tested insecticides exhibited a significantly reduction in cotton aphids' populations in all days $(2,5$, $8,11,14$ days) after treatment. According to the general mean of reduction in aphids' populations throughout the experiment periods, imidacloprid proved to be the most effective compound recording $92.95 \%$ reduction in 2017 season followed by flonicamid (86.36\%). Next effective treatments were dinotefuran $(76.16 \%)$, carbosulfan $(77.47 \%)$, chlorpyrifos $(77.05 \%)$ and malathion $(75.34 \%)$ without significantly differences between them, while abamectin was the least effective compound (71.68\%). In 2018 season, the results recorded the same trend as in 2017 season (Table2), where imidacloprid was the best insecticide in reduction of A. gossypii (90.95\%), followed by flonicamid, dinotefuran and abamectin giving 82.48, 78.44 and $79.14 \%$, respectively without significant difference. Malathion was the least compound causing $61.78 \%$ reduction in populations. The present findings are in conformity with Abd-Ella, 2013 and Ghelani et al., 2014) who observed effectiveness of flonicamid, acetamiprid, imidacloprid and dinotefuran against cotton aphids. Also, Sathyan et al., 2016 and Nemade et al.,2017) found that neonicotinoid compounds and flonicamid were effective against $A$. gossypii 
Table 1. Efficacy of different insecticides against Aphis gossypii on cotton plants under field condition during season 2017 at Kafr El- Sheikh Governorate

\begin{tabular}{|c|c|c|c|c|c|c|c|c|}
\hline \multirow{3}{*}{ Insecticide } & \multirow{3}{*}{$\begin{array}{c}\text { Rate } / 100 \\
\text { L }\end{array}$} & \multirow{3}{*}{ Pre-spray } & \multicolumn{5}{|c|}{ Reduction of A. gossypii during season 2017} & \multirow{3}{*}{$\begin{array}{c}\text { Mean } \\
\%\end{array}$} \\
\hline & & & \multicolumn{5}{|c|}{ Post spray at indicated days } & \\
\hline & & & 2 & 5 & 8 & 11 & 14 & \\
\hline Flonicamid & $45 \mathrm{~g}$ & 10.72 & 96.76 & 93.32 & 91.13 & 78.73 & 71.88 & $86.36^{\mathrm{b}}$ \\
\hline Dinotefuran & $125 \mathrm{~g}$ & 10.04 & 91.73 & 82.28 & 75.44 & 69.72 & 61.65 & $76.16^{\mathrm{cd}}$ \\
\hline Imidacloprid & $75 \mathrm{ml}$ & 11.28 & 98.8 & 99.79 & 97.86 & 85.31 & 83.03 & $92.95^{\mathrm{a}}$ \\
\hline Abamectin & $40 \mathrm{ml}$ & 16.96 & 79.04 & 76.94 & 68.04 & 68.0 & 66.0 & $71.68^{d}$ \\
\hline Carbosulfan & $27 \mathrm{ml}$ & 9.16 & 86.89 & 80.16 & 79.52 & 75.11 & 65.66 & $77.47^{\mathrm{c}}$ \\
\hline Malathion & $50 \mathrm{ml}$ & 9.84 & 84.69 & 79.03 & 72.76 & 70.65 & 69.59 & $75.34^{\mathrm{cd}}$ \\
\hline Chlorpyrifos & $333.3 \mathrm{ml}$ & 10.12 & 88.93 & 87.67 & 71.66 & 70.26 & 66.74 & $77.05^{\mathrm{c}}$ \\
\hline control & - & 16.08 & $33.28^{*}$ & $20.84^{*}$ & $12.04^{*}$ & $10.56^{*}$ & $7.28^{*}$ & \\
\hline
\end{tabular}

* No. of A. gossypii /cotton leaf during the experiment in control

In the same column, means followed by the same letters are not significantly differed, $\mathrm{p}=0.05$ by Duncan (1955).

Table 2. Efficacy of different insecticides against Aphis gossypii on cotton plants under field condition during season 2018 at Kafr El- Sheikh Governorate

\begin{tabular}{|c|c|c|c|c|c|c|c|c|}
\hline \multirow{3}{*}{ Insecticide } & \multirow{3}{*}{$\begin{array}{c}\text { Rate/100 } \\
\text { L) }\end{array}$} & \multirow{3}{*}{ Pre-spray } & \multicolumn{5}{|c|}{ Reduction of A. gossypii during season 2018} & \multirow{3}{*}{$\begin{array}{c}\text { Mean } \\
\%\end{array}$} \\
\hline & & & \multicolumn{5}{|c|}{ Post spray at indicated days } & \\
\hline & & & 2 & 5 & 8 & 11 & 14 & \\
\hline Flonicamid & $45 \mathrm{~g}$ & 15.48 & 91.89 & 89.86 & 88.93 & 71.42 & 70.28 & $82.48^{\mathrm{b}}$ \\
\hline Dinotefuran & $125 \mathrm{~g}$ & 16.72 & 91.5 & 81.3 & 79.87 & 72.26 & 67.26 & $78.44^{\mathrm{b}}$ \\
\hline Imidacloprid & $75 \mathrm{ml}$ & 18.96 & 96.03 & 97.49 & 89.91 & 89.15 & 82.17 & $90.95^{\mathrm{a}}$ \\
\hline Abamectin & $40 \mathrm{ml}$ & 21.92 & 88.77 & 83.52 & 79.9 & 72.27 & 71.25 & $79.14^{\mathrm{b}}$ \\
\hline Carbosulfan & $27 \mathrm{ml}$ & 15.72 & 88.9 & 76.28 & 71.58 & 67.52 & 64.74 & $73.8^{\mathrm{bc}}$ \\
\hline Malathion & $50 \mathrm{ml}$ & 16.32 & 78.07 & 66.45 & 57.72 & 56.03 & 50.67 & $61.79^{\mathrm{d}}$ \\
\hline Chlorpyrifos & $333.3 \mathrm{ml}$ & 22.76 & 90.78 & 79.02 & 61.01 & 58.45 & 54.42 & $68.74^{c}$ \\
\hline Control & - & 35 & $57.96^{*}$ & $28.24^{*}$ & $21.72^{*}$ & $17.84^{*}$ & $11.8^{*}$ & \\
\hline
\end{tabular}

* No. of A. gossypii /cotton leaf during the experiment in control.

In the same column, means followed by the same letters are not significantly differed, $p=0.05$ by Duncan (1955)

\section{Efficacy of tested insecticides against Bemisia tabaci (Genn.):}

Reduction percentages of the tested insecticides against adults and immature stages of $B$. tabaci were registered in Table (3-6). The data in Table (3 and 4) noticed that all the tested insecticides exhibited significantly depression in populations of $B$. tabaci adults compared to control in 2017 and 2018 cotton seasons. Imidacloprid proved to be the most effective one giving $78.46 \%$ and $75.85 \%$ in 2017 and 2018 seasons, respectively. Next effective treatments were dinotefuran, flonicamid and malathion producing reduction ranged from $64.92-68.03 \%$ in 2017 , while in 2018 , dinotefuran, abamectin and flonicamid exhibited significant reduction ranged from 69.47 to $73.99 \%$. It is important to note that carbosulfan was the least effective producing 49.69 and $59.45 \%$ reduction in 2017 and 2018 seasons, respectively.

The effect of the tested insecticides against immature stages of $B$. tabaci, were summarized in Tables (5and 6). The data revealed that imidacloprid, flonicamid and chlorpyrifos were the most effective without significantly differences causing 81.61, 78.21 and $78.06 \%$ reduction, respectively in 2017 season, while abamectin recorded the least effect (63.76\%) against immature stages. The same trend was also observed in 2018 season. On the other hand, the tested insecticides were more effective against immature stages than adults B. tabaci, our study proved that imidacloprid, flonicamid and dinotefuran were higher significant in suppressing populations of B. tabaci. These results are consistent with data reported by that (Kalyan et al.,2012; Gourkhede et al., 2015 and Ghelani et al.,2014) who reported that flonicamid and imidacloprid were effective against $B$. tabaci in cotton fields. Also, Roditakis et al., 2014; Sathyan et al., 2016 and Nemade et al., 2017 found that flonicamid at rate $75 \mathrm{~g}$ a.i./ha and flonicamid at $100 \mathrm{~g}$ a.i./ha and imidacloprid managed B. tabaci populations. 
Table 3. Efficacy of different insecticides against adult stage of Bemisia tabaci (Genn.) on cotton plants under field condition during season 2017 at Kafr El- Sheikh Governorate

\begin{tabular}{|c|c|c|c|c|c|c|c|c|}
\hline \multirow{3}{*}{ Insecticide } & \multirow{3}{*}{$\begin{array}{c}\text { Rate/10 } \\
\text { OL }\end{array}$} & \multirow{3}{*}{$\begin{array}{l}\text { Pre- } \\
\text { spray }\end{array}$} & \multicolumn{5}{|c|}{ percent reduction of B.tabaci during season 2017} & \multirow{3}{*}{ Mean $\%$} \\
\hline & & & \multicolumn{5}{|c|}{ Post spray at indicated days } & \\
\hline & & & 2 & 5 & 8 & 11 & 14 & \\
\hline Flonicamid & $45 \mathrm{~g}$ & 11.04 & 61.65 & 62.43 & 75.89 & 70.74 & 67.0 & $67.54^{\mathrm{bc}}$ \\
\hline Dinotefuran & $125 \mathrm{~g}$ & 13.92 & 61.21 & 66.7 & 73.49 & 75.09 & 63.65 & $68.03^{b}$ \\
\hline Imidacloprid & $75 \mathrm{ml}$ & 10.12 & 62 & 78.75 & 84.31 & 87.23 & 80.0 & $78.46^{\mathrm{a}}$ \\
\hline Abamectin & $4 \mathrm{o} \mathrm{ml}$ & 16.4 & 68.13 & 68.47 & 64.15 & 58.12 & 54.27 & $62.63^{\mathrm{cd}}$ \\
\hline Carbosulfan & $27 \mathrm{ml}$ & 15.04 & 39.68 & 53.02 & 57.78 & 51.17 & 46.84 & $49.69^{\mathrm{e}}$ \\
\hline Malathion & $50 \mathrm{ml}$ & 12.16 & 53.11 & 67.58 & 69.9 & 69.9 & 64.21 & $64.92^{\text {bcd }}$ \\
\hline Chlorpyrifos & $333.3 \mathrm{ml}$ & 15.2 & 49.33 & 64.46 & 71.09 & 66.18 & 59.35 & $62.08^{c d}$ \\
\hline Control & - & 15.2 & $14.04^{*}$ & $11.8^{*}$ & $10.36^{*}$ & $8.9^{*}$ & $6^{*}$ & \\
\hline
\end{tabular}

* No. of B.tabaci adults /cotton leaf during the experiment in control.

In the same column, means followed by the same letters are not significantly differed, $\mathrm{p}=0.05$ by Duncan (1955).

Table 4. Efficacy of different insecticides against adult stage of Bemisia tabaci(Genn). on cotton plants under field condition during season 2018 at Kafr El- Sheikh Governorate

\begin{tabular}{ccccccccc}
\hline \multirow{2}{*}{ Insecticide } & Rate & \multirow{2}{*}{ Pre-spray } & \multicolumn{5}{c}{ Reduction of B.tabaci during season 2018 } & \multirow{2}{*}{ Mean \% } \\
\cline { 4 - 7 } & & \multicolumn{4}{c}{ Post spray at indicated days } & \multicolumn{4}{c}{11} & 14 & \\
\hline Flonicamid & $45 \mathrm{~g}$ & 10.72 & 74.4 & 60.35 & 67.96 & 73.37 & 71.36 & $69.47^{\mathrm{bc}}$ \\
Dinotefuran & $125 \mathrm{~g}$ & 14.88 & 71.28 & 69.95 & 77.56 & 78.07 & 73.08 & $73.99^{\mathrm{a}}$ \\
Imidacloprid & $75 \mathrm{ml}$ & 7.0 & 69.2 & 80.29 & 79.57 & 77.26 & 72.92 & $75.85^{\mathrm{a}}$ \\
Abamectin & $40 \mathrm{ml}$ & 14.52 & 76.51 & 77.57 & 70.1 & 69.87 & 69.8 & $72.71^{\mathrm{ab}}$ \\
Carbosulfan & $27 \mathrm{ml}$ & 13.4 & 47.05 & 58.81 & 63.22 & 65.84 & 62.34 & $59.45^{\mathrm{d}}$ \\
Malathion & $50 \mathrm{ml}$ & 10.52 & 58.92 & 65.89 & 73.1 & 68.22 & 63.2 & $65.87^{\mathrm{c}}$ \\
Chlorpyrifos & $333.3 \mathrm{ml}$ & 13.96 & 51.7 & 60.49 & 60.14 & 66.92 & 57.92 & $59.43^{\mathrm{d}}$ \\
Control & - & 13.12 & $13.28^{*}$ & $9.52^{*}$ & $8.24^{*}$ & $6.58^{*}$ & $4.92^{*}$ & - \\
\hline
\end{tabular}

* No. of B.tabaci adults /cotton leaf during the experiment in control.

In the same column, means followed by the same letters are not significantly differed, $\mathrm{p}=0.05$ by Duncan (1955).

Table 5. Efficacy of different insecticides against immature stages of Bemisia tabaci(Genn.) on cotton plants under field condition during season 2017 at Kafr El- Sheikh Governorate

\begin{tabular}{|c|c|c|c|c|c|c|c|c|}
\hline \multirow{3}{*}{ Insecticide } & \multirow{3}{*}{$\begin{array}{c}\text { Rate /100 } \\
\text { L }\end{array}$} & \multirow{3}{*}{ Pre-spray } & \multirow{2}{*}{\multicolumn{5}{|c|}{$\begin{array}{l}\text { Reduction immature stages of B.tabaci during season } \\
2017 \\
\text { Post spray at indicated days }\end{array}$}} & \multirow{3}{*}{ Mean $\%$} \\
\hline & & & & & & & & \\
\hline & & & 2 & 5 & 8 & 11 & 14 & \\
\hline Flonicamid & $45 \mathrm{~g}$ & 7.68 & 78.33 & 86.13 & 80.35 & 78.23 & 67.99 & $78.21^{\mathrm{ab}}$ \\
\hline Dinotefuran & $125 \mathrm{~g}$ & 6.24 & 67.18 & 71.38 & 73.06 & 72.6 & 70.97 & $71.04^{c}$ \\
\hline Imidacloprid & $75 \mathrm{ml}$ & 9.84 & 74.09 & 88.44 & 83.7 & 86.83 & 75.01 & $81.61^{\mathrm{a}}$ \\
\hline Abamectin & $40 \mathrm{ml}$ & 11.36 & 35.1 & 74.39 & 77.63 & 71.23 & 60.13 & $63.76^{\mathrm{d}}$ \\
\hline Carbosulfan & $27 \mathrm{ml}$ & 7.4 & 55.72 & 67.31 & 77.8 & 68.16 & 62.4 & $66.28^{d}$ \\
\hline Malathion & $50 \mathrm{ml}$ & 10.84 & 71.42 & 83.79 & 89.43 & 76.86 & 64.69 & $77.26^{\mathrm{b}}$ \\
\hline Chlorpyrifos & $333.3 \mathrm{ml}$ & 13.76 & 72.47 & 83.05 & 85.56 & 82.6 & 66.62 & $78.06^{\mathrm{ab}}$ \\
\hline Control & - & 15.52 & $12.12^{*}$ & $10.8^{*}$ & $8.12^{*}$ & $4.08^{*}$ & $2.48^{*}$ & \\
\hline
\end{tabular}

* No. of B.tabaci immature stages /cotton leaf during the experiment in control.

In the same column, means followed by the same letters are not significantly differed, $\mathrm{p}=0.05$ by Duncan (1955) 
Table 6. Efficacy of different insecticides against immature stages of Bemisia tabaci (Genn.) on cotton plants under field condition during season 2018 at Kafr El- Sheikh Governorate

\begin{tabular}{ccccccccc}
\hline & & & \multicolumn{6}{c}{ Reduction immature stages of B.tabaci during season } \\
Insecticide & Rate /100 & Pre- & \multicolumn{5}{c}{ 2018 } \\
\cline { 4 - 7 } & $\mathrm{L}$ & spray & \multicolumn{5}{c}{ Post spray at indicated days } \\
\cline { 4 - 7 } & & & 2 & 5 & 8 & 11 & 14 \\
\hline Flonicamid & $45 \mathrm{~g}$ & 10.48 & 87.43 & 93.19 & 92.11 & 80.53 & 73.26 & $85.3^{\mathrm{a}}$ \\
Dinotefuran & $125 \mathrm{~g}$ & 8.32 & 72.08 & 80.12 & 77.02 & 74.04 & 72.5 & $75.15^{\mathrm{b}}$ \\
Imidacloprid & $75 \mathrm{ml}$ & 10.16 & 88.09 & 94.89 & 90.59 & 92.03 & 70.72 & $87.26^{\mathrm{a}}$ \\
Abamectin & $40 \mathrm{ml}$ & 10.84 & 48.15 & 61.04 & 75.49 & 77.86 & 53.04 & $63.12^{\mathrm{d}}$ \\
Carbosulfan & $27 \mathrm{ml}$ & 9.0 & 73.75 & 86.56 & 90.64 & 80.33 & 60.6 & $78.38^{\mathrm{b}}$ \\
Malathion & $50 \mathrm{ml}$ & 8.0 & 61.4 & 64.09 & 73.68 & 70.75 & 59.96 & $65.98^{\mathrm{d}}$ \\
Chlorpyrifos & $333.3 \mathrm{ml}$ & 9.36 & 69.02 & 66.63 & 68.15 & 79.81 & 70.67 & $70.84^{\mathrm{c}}$ \\
Control & - & 8.92 & $9.96^{*}$ & $8.24^{*}$ & $6.16^{*}$ & $2.93^{*}$ & $1.56^{*}$ & - \\
\hline
\end{tabular}

* No. of B.tabaci immature stages /cotton leaf during the experiment in control.

In the same column, means followed by the same letters are not significantly differed, $\mathrm{p}=0.05$ by Duncan $(1955)$.

\section{Efficacy of tested insecticides against associated predators:}

Reduction percentages of associated predators, chrysoperla carnea (adults and larvae) and spiders was recorded in figure (1). The data showed that flonicamid, imidacloprid and abamectin have little effect on the predators compared the other tested insecticides, where they reduced populations ranged from 11.87 to $19.73 \%$ in 2017 season and from 19.16 to $25.25 \%$ reduction in 2018 season. Dinotefuran and carbosulfan exhibited moderate harmful to predators producing $26.21 \%$ and $31.71 \%$ reduction in 2017 season and 31.7 and $44.32 \%$ reduction in 2018 season, respectively. It is important to note that tested predators under field conditions was reduced by chlorpyrifos recoding 58.59 and $68.43 \%$ in 2017 and 2018 seasons, respectively. These results decided that flonicamid, imidacloprid and dinotefuran were low toxic effect than the tested organophosphates and carbosulfan to the tested predators. The current results are in harmony with Hautier et al., (2006) who observed that flonicamid was less harmful than organophosphates, pyrethroids and neonicotinoids to the beneficial arthropods in the open field. In addition, Colomer et al., 2011; Ghelani et al., 2014 and El-Zahi et al., 2017 found that flonicamid was safer than imidacloprid and thiamethoxam to coccinellids and chrysopids under field conditions.

On the basis of the current investigation, it can be concluded that flonicamid, imidacloprid and dinotefuran have high activity against Aphis gossypii Glover and Bemisia tabaci (Genn.). Also, they were less harmful to the tested predators on cotton plants under field conditions. So, these insecticides represent an important choice to use in IPM programs to control these pests in cotton fields. 


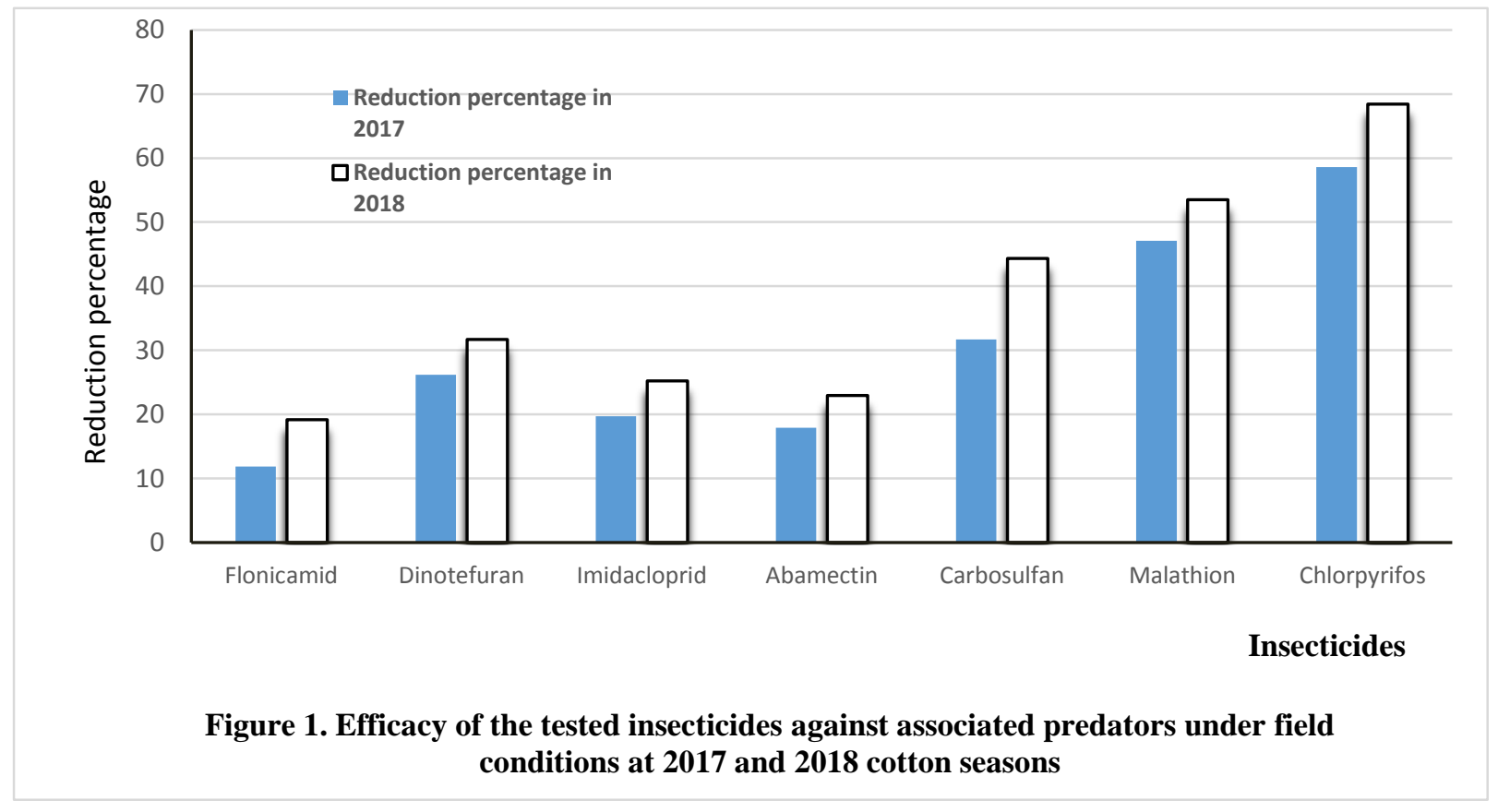

\section{REFERENCES}

Abd-Ella, A.A. 2013. Toxicity and persistence of selected neonicotinoid insecticides on cowpea aphid, Aphis gossypii Koch (Homoptera: Aphididae). Phytopathol. and Plant Prot. 47(3): 366-376.

Berlinger, M. J. 1986. Host plant resistance to Bemisia tabaci. Agric. Ecosystems Environ. 17: 69-82.

Blackman, R. L. and V. R. Eastop. 1984. Aphids on the world's crops: An Identification Guide. John Wiley and sons., New York.

Colomer, I., P. Aguado, P. Medina, R. M. Heredia, A. Fereres and J. E. Belda. 2011. Field trial measuring the compatibility of methoxyfenozide and flonicamid with Orius leavigatus Fieber (Hemiptera: Anthocoridae) and Amblyseius swirskii (Athias-Henriot) (AcariPhytoseiidae) in a commercial pepper greenhouse. Pest Manag. Sci. 67: 1237-1244.

Costat program. 2005. Microcomputer program analysis, Cohort software, version 6.311, Montere, CA, USA.

Duncan, D.B. 1955. Multiple range and multiple f-tests. Biometrics. 11: 1-42.

El-Zahi, S. E., E. A. El-Sarand and G.N. El-Masry. 2017. Activity of flonicamid and two neonicotinoid insecticides against Bemisia tabaci (Gennadius) and its associated predators on cotton plants. Egypt. Acad. J. Biolog. Sci. 10(8): 25-34.

Forlow, J.L. and T. J. Henneberry . 2001. Cotton aphid biology honeydew production. Arizona Cotton Report. Pp: 282-289.
Ghelani, M. K.,B. B. Kabaria and S. K. Chhodavadia. 2014. Field efficacy of various insecticides major sucking pests of Bt cotton. J. Biopest 7:27-32.

Gourkhede, A. S., S.K. Bhalkare, A. K. Sadawarte and D. B. Undirwade. 2015. Bioefficacy of new chemistry molecules against sucking pests of Bt transgenic cotton. Int. J. Plant Prot., 8(1): 7-12.

Hautier, L., J. P. Jansen, N. Mabon and B. Schiffers. 2006. Building a selectivity list of plant protection products on beneficial arthropods in open field: a clear example with potato crop. IOBC/ WPRS bulletin 29 (10): 21-32.

Henderson C.F. and E.W. Tilton. 1955. Test with acaricides against the brown wheat mite. J. Econ. Entomol. 48: 157161.

Horowitz, A. R.; Z. Mendelson; P. G. Weintraub and I. Ishaaya. 1998. Comparative toxicity of foliar and systemic applications of acetamiprid and imidacloprid against the cotton whitefly, Bemisia tabaci (Homoptera: Aleyrodidae). Bull. Entomol. Res. 88: 437-442.

Hunter, W. B. and J. E. Polston. 2001. Development of a continuous whitefly cell line (Homoptera: Aleyrodidae) Bemisia tabaci (Gennadius) for the study of Begomovirus. J. Invert. Pathol. 77:33-36.

Jorge, S. and O. Mendoza. 1995. Biology of the sweet potato whitefly (Homoptera: Aleyrodidae) on tomato. Florida Entomol. 78: 154-160.

Kalyan, R. K., D. P. Saini, P. P. Jambhulkar and A. Pareek. 2012. Comparative bio efficacy of some new molecules against jassids and whiteflies in cotton. Bioscan. 7(4): 641-643. 
Li, F., Z. Han, Z. Wu and Y. Wang. 2001. Insecticide resistance of Aphis gossypii Glover in cotton in china. Cotton Sci. 13: 121-124.

Maienfisch, P. L., H. Huerlimann, A.Rindlisbacher, L. Gsell, H. Dettwiler, J. Haettenschwiler, E. Sieger and M. Walti. 2001. The discovery of thiamethoxam: a secondgeneration neonicotinoid. Pest Manag. Sci. 57:165-176.

Morita, M., T. Ueda, T. Toneda, T. Koyanagi and T. Haga. 2007. Flonicamid a novel insecticide with a rapid inhibitory effect on aphid feeding. Pest Manag. Sci. 63: 969-973.
Nemade, P. W., T. H. Rathod, S.B. Deshmukh, V.V. Ujjainkar and V.V. Deshmukh. 2017. Evaluation of new molecules against sucking pests of Bt cotton. J. Entomol. Zool. Studies. 5(6): 659-663.

Roditakis, E., N. Fytrou, M. Staurakaki, J. Vontas and A. Vontas and A. Tsagkarakou. 2014. Activity of flonicamid on sweet potato whitefly,Bemisia tabaci (Homoptera: Aleyrodidae) and its natural enemies. Pest Manag. Sci. 70 (10): 1460-1467.

Sathyan, T., N. Murugesan, K. Elanchezhyan, J. Arockia Stephen Raj and G.Ravi. 2016. Efficacy of synthetic insecticides against sucking insect pests in cotton, Gossypium hirsutum L. Int. J. Entomol. Res. 1(1): 16-21.

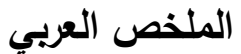

\section{فاعلية المبيدات المخلقة على من القطن والذبابة البيضاء ويعض المفترسات المرتبطة بهما على نباتات القطن}

$$
\text { مديحة الصباحى حامد الديوى ، أنيسة صابر صادق، السيد أحمد الصرند }
$$

كربوسلفان و كلوربيرفوس تأثيرا متوسطا معنويا فى خفض تعداد المن ، بينما كان مبيد الملاثيون أقلها فاعلية على المن ، بالنسبة لتأثنر المبيدات المختبرة على الذبابة البيضاء

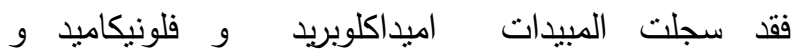
داينيتفيوران أعلى تأثثر على الطور الكامل للذبابة البيضاء

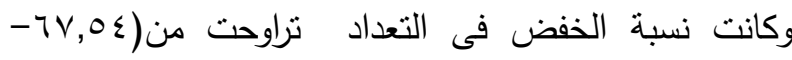

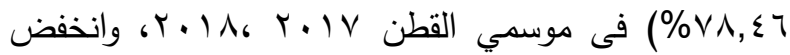
تعداد الطور الغير كامل للذبابة البيضاء من (ع +, (Y)

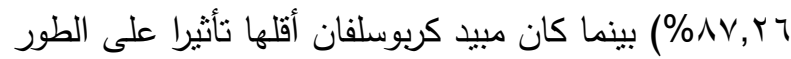
الكامل والغير الكامل للذبابة البيضاء ،وأنشارت النتائج أن مبيدات اميداكلوبريد و فلونيكامبد و د داينيتفيوران أقل سمية على أكثر المفترسات المصاحبة انتشارا عن المبيدات الفوسفورية العضوية المختبرة وعن مبيد كربوسلفان .مما

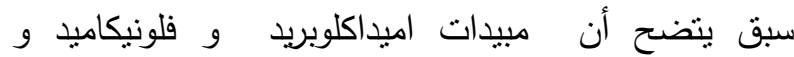
داينيتفيوران يمكن اختيارهم للاستخدام ضمن برامج المكافحة المتكاملة لمن القطن والذبابة البيضاء فى حقول القطن.
مركبات مجموعتي بيرودانيكربكساميد و نيونيكونينيد من المبيدات الكيميائية التى تستخدم بمعدلات صغيرة ولها أهمية اقتصادية فى مكافحة الأفات الثاقبة الماصة فى حقول القطن ، لذا تهدف هذه الدراسة تقييم فاعلية مبيد فلونيكاميد و اميداكلوبريد و د داينيتفيوران ومقارنتهم فاعليتهم بمبيدات أخرى منل أبامكتين ،كربوسلفان ،ملاثيون و كلوربيرفوس على دئى من القطن والذبابة البيضاء ودراسة تأثيرهم على بعض ابض المفترسات المرتبطة بهما منل أسد المن (اليرقة والحشرة الكاملة) والعناكب الحقيقية .أجريت الدراسة بالمزرعة البحثية بسخا بمحافظة كفر الثيخ وذلك فى موسمى القطن

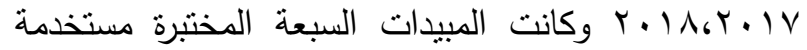
بالمعدلات الموصي بها .أوضحت النتائج أن مبيد امبداكلوبريد و فلونيكاميد و داينيتفيوران أكثر المبيدات فاعليةعلى من القطن وكانت نسبة الخفض فى التعداد ( )

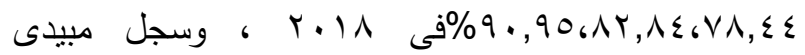

